\title{
Thrombin-Induced Protein
}

\section{Phosphorylation in Human Platelets}

\author{
Roger M. Lyons, Nancy Stanford, and Phimip W. Majerus \\ From the Divisions of Hematology and Oncology, the Departments of Internal \\ Medicine and Biochemistry, Washington University School of Medicine, \\ St. Louis, Missouri 63110
}

A B S T R A C T Intact human platelets loaded with ${ }^{82} \mathrm{PO}$ contain multiple phosphorylated proteins. Thrombin treatment of intact ${ }^{22} \mathrm{PO}_{4}$-loaded platelets results in a 2-6-fold increase in phosphorylation of a platelet protein (designated "peak 7" protein) of approximately $40,000 \mathrm{~mol}$ wt as determined by sodium dodecyl sulfate polyacrylamide gel electrophoresis and by gel filtration on Sephadex G-150. A similar increase in phosphorylation was observed in a platelet protein (designated "peak 9" protein) of approximately $20,000 \mathrm{~mol} \mathrm{wt}$. The time for half-maximal phosphorylation of peak 7 and peak 9 protein was $10-14 \mathrm{~s}$. The concentration of thrombin at half-maximal phosphorylation was $0.25 \mathrm{U} / \mathrm{ml}$ for both proteins. Prior incubation of platelets with dibutyryl cyclic adenosine 3',5'-monophosphate or prostaglandin $E_{1}$ inhibited thrombin-induced peak 7 and peak 9 protein phosphorylation. The erythroagglutinating phytohemagglutinin of Phaseolus vulgaris, a non-proteolytic release-inducing agent, induced peak 7 and peak 9 protein phosphorylation. Thus, the characteristics of peak 7 and peak 9 protein phosphorylation are similar to those of the platelet release reaction, suggesting that the phosphorylation of these proteins may play a role in the platelet release reaction.

When platelet sonicates or the supernatant fraction from platelet sonicates were incubated with $\left[\gamma-{ }^{28} \mathrm{P}\right] \mathrm{ATP}$ there was phosphorylation of both peak 7 and peak 9 proteins. This phosphorylation was unaffected by either added thrombin or adenosine $3^{\prime}, 5^{\prime}$-cyclic monophosphate (cAMP) despite the presence of the phosphodiesterase inhibitor 1-methyl-3-isobutylxanthine. Thus, the throm-

This work was reported in part at the American Society for Clinical Investigation Meeting, Atlantic City, N. J., May 1974 (1).

Dr. Lyons' present address: Division of Hematology, Department of Medicine, Veterans Administration Hospital, University of Texas Health Science Center at San Antonio, Tex. 78284.

Received for publication 20 March 1975 and in revised form 9 June 1975 . bin-dependent phosphorylation depends upon intact platelets. When the supernatant fraction from platelet sonicates was fractionated by histone-Sepharose affinity chromatography, two distinct protein kinase enzymes were resolved, one a cAMP-dependent holoenzyme and the other a cAMP-independent enzyme. The isolated cAMP-dependent enzyme fraction catalyzed the cAMP(but not thrombin-) stimulated phosphorylation of a protein that co-electrophoresed with peak 7 protein.

\section{INTRODUCTION}

Evidence has been presented in recent years suggesting that platelet aggregation and the release reaction may be controlled by variations in intracellular adenosine $3^{\prime}, 5^{\prime}$ cyclic monophosphate (cAMP) ${ }^{1}$ levels (2). Thrombin, a potent inducer of the platelet release reaction, has been shown to bind to receptors on the platelet surface $(3,4)$ and to decrease the activity of platelet adenylate cyclase without a change in phosphodiesterase activity (5). In other tissues the effects of cAMP are mediated through changes in protein phosphorylation resulting from a cAMP-induced alteration in protein kinase and/ or phosphoprotein phosphatase activity (6-8). In many tissues increasing cAMP is associated with increased protein kinase activity although recently the opposite response, namely inhibition of protein kinase activity by rising cAMP has also been described $(9,10)$. The cAMP-dependent protein kinases are relatively nonspecific, and their physiologically important endogenous substrates have been difficult to identify in cell homogenates (6). Thus we have studied protein phosphorylation in both intact platelets and platelet homogenates in

\footnotetext{
1 Abbreviations used in this paper: cAMP, adenosine $3^{\prime}, 5^{\prime}-$ cyclic monophosphate; DB-cAMP, $N^{6}-2^{\prime}, 0^{\prime}$-dibutyryl cAMP; DFP, diisopropyl fluorophosphate; E-PHA, erythroagglutinating phytohemagglutinin of Phaseolus vulgaris; $\mathrm{PGE}_{1,}$ prostaglandin $\mathrm{E}_{1}$; SDS, sodium dodecyl sulfate; TPCK, L-(tosylamido 2-phenyl) ethyl-chloromethyl ketone.
} 
an attempt to define potential physiologic substrates of the platelet protein kinases.

We report here that thrombin treatment of intact platelets results in a 2-6-fold increase in phosphorylation of two proteins of mol wt 40,000 (peak 7) and 20,000 (peak 9) and that agents which elevate intracellular cAMP block this reaction. In disrupted platelets proteins of molecular weight similar to peak 7 and 9 proteins are phosphorylated by $\left[\gamma^{32} \mathrm{P}\right] \mathrm{ATP}$. However, these latter phosphorylation reactions are unaffected by either thrombin or cAMP, suggesting that the normal control mechanisms of platelet protein phosphorylation are disrupted during cell lysis.

Further, we have studied the characteristics of two platelet protein kinases resolved from platelet homogenates, one of which appears to be a typical cAMPdependent holoenzyme while the other is unaffected by cAMP. The cAMP-dependent enzyme fraction catalyzes the phosphorylation of a protein that co-electrophoreses with peak 7 protein. This phosphorylation is stimulated twofold by cAMP.

\section{METHODS}

Isotopes were purchased from the following sources: [ $\gamma-$ $\left.{ }^{32} \mathrm{P}\right]$ ATP $(5 \mathrm{Ci} / \mathrm{mmol})$, serotonin $\left[2{ }^{14} \mathrm{C}\right]$ binoxalate $(27.5$ $\mathrm{mCi} / \mathrm{mmol}),\left[\gamma^{-32} \mathrm{P}\right] \mathrm{GTP}(26 \mathrm{Ci} / \mathrm{mmol})$, and $\left[{ }^{3} \mathrm{H}\right] \mathrm{cAMP}$ $(20 \mathrm{Ci} / \mathrm{mmol})$, New England Nuclear, Boston, Mass. ; carrier-free $\mathrm{H}_{3}^{32} \mathrm{PO}_{4}(50 \mathrm{mCi} / \mathrm{ml})$ and carrier-free $\left[{ }^{225} \mathrm{I}\right]$ sodium iodide $(50 \mathrm{mCi} / \mathrm{ml})$, Mallinckrodt Chemical Works, St. Louis, Mo. Millipore filters (RAWP-025-000, 1.2- $\mu \mathrm{m}$ pore size, $25-\mathrm{mm}$ diameter) were purchased from Millipore Corp., Bedford, Mass., and Gelman filters type GN6, 0.45$\mu \mathrm{m}$ pore size, $25-\mathrm{mm}$ diameter, were obtained from Fisher Scientific Co., Pittsburgh, Pa. RP/R-54 Royal X-Omat medical X-ray film was obtained from Eastman Kodak Co., Rochester, N. Y. Highly purified ( $>94 \%$ pure) Escherichia coli alkaline phosphatase was a gift of Dr. M. Schlesinger (11). Dowex 1 (AG1-X8, 100-200 mesh, chloride form) and AG 501-X8 mixed bed ion exchange resin were purchased from Bio-Rad Laboratories, Richmond, Calif. 1-Methyl-3-isobutylxanthine was a gift from Dr. Lewis Chase. Prostaglandin $\mathrm{E}_{1}\left(\mathrm{PGE}_{1}\right)$ was a gift from Dr. John Pike, the Upjohn Co., Kalamazoo, Mich.

Bovine thrombin, purified from topical thrombin (Parke, Davis \& Company, Detroit, Mich.) by the method of Glover and Shaw (12), yielded a clotting activity of $2,700 \mathrm{U} / \mathrm{mg}$ thrombin. Homogeneous human thrombin with a clotting activity of 2,600 U/mg was a gift from Dr. John Fenton. L-(Tosylamido 2-phenyl) ethyl-chloromethyl ketone (TPCK) trypsin was purified by the method of Kostka and Carpenter (13). Erythroagglutinating phytohemagglutinin of Phaseolus vulgaris (E-PHA) was purified from Bacto phytohemagglutinin P (Difco Laboratories, Detroit, Mich.), as previously described (14).

Platelet preparation and se $\mathrm{PO}_{4}$ loading. Platelets were isolated by differential centrifugation as previously described from fresh EDTA-anticoagulated human blood or from acid citrate dextrose-anticoagulated 72-h-old platelet concentrates (for large-scale preparations) beginning with the first 2,250- $g$ centrifugation (15). The isolation was carried out at room temperature in isotonic phosphate-buf- fered saline, $\mathrm{pH}$ 6.5, containing $0.113 \mathrm{M} \mathrm{NaCl}, 0.0043 \mathrm{M}$ $\mathrm{K}_{2} \mathrm{HPO}_{4}, 0.0043 \mathrm{M} \mathrm{Na}_{2} \mathrm{HPO}_{4}, 0.0244 \mathrm{M} \mathrm{NaH} \mathrm{PO}_{4}$, and $0.0055 \mathrm{M}$ glucose. The isolated platelets were resuspended at $0.1-1 \times 10^{9}$ platelets $/ \mathrm{ml}$ in $35 \mathrm{ml}$ isotonic Tris-buffered saline, $\mathrm{pH} 7.4$, containing $0.14 \mathrm{M} \mathrm{NaCl}, 0.015 \mathrm{M}$ Tris- $\mathrm{HCl}$, and $0.0055 \mathrm{M}$ glucose ("resuspension buffer") and incubated for $15 \mathrm{~min}$ to deplete them of phosphate. The platelets were then sedimented at $2,250 \mathrm{~g}$ for $15 \mathrm{~min}$ at room temperature and resuspended in $35 \mathrm{ml}$ of the same buffer for a further 15-min incubation. The platelets were sedimented again at 2,250 g for $15 \mathrm{~min}$ and resuspended in a small volume of resuspension buffer, and the platelet concentration was estimated from the packed cell volume of the platelet suspension by assuming that a $1 \%$ packed cell volume equals $1 \times 10^{9}$ platelets $/ \mathrm{ml}(3,15)$. The platelet suspension was adjusted to contain $2 \times 10^{\circ}$ platelets $/ \mathrm{ml}$ and $0.5 \mathrm{mCi} / \mathrm{ml}^{32} \mathrm{PO}_{4}$ adjusted to $\mathrm{pH} 7-7.5$ with $\mathrm{NaOH}$. Incubation at room temperature for $60 \mathrm{~min}$ served to load the platelets with ${ }^{32} \mathrm{PO}_{4}$. For most experiments reactions were carried out in a total volume of $0.025-0.125 \mathrm{ml}$ in either $500-\mu 1$ polyethylene or $1.5-\mathrm{ml}$ polypropylene microtest tubes (Brinkmann Instruments, Inc., Westbury, N. Y.). Platelets prepared from fresh whole blood were used for most studies of intact platelets, and the use of outdated platelets for a particular experiment is indicated in the text.

Preparation of crude supernate for protein kinase studies. Platelets for protein kinase studies were isolated in isotonic phosphate-buffered saline, $\mathrm{pH} 6.5$, from either fresh blood or 72 -h-old platelet concentrations as described above. They were then washed an additional time with resuspension buffer and suspended in the same buffer at a concentration of $20-30 \times 10^{\circ}$ platelets $/ \mathrm{ml}$. The platelet suspension was then frozen in liquid nitrogen and stored at $-90^{\circ} \mathrm{C}$ until a sufficient quantity had been accumulated. To obtain a crude supernatant fraction, the frozen suspensions were thawed at $37^{\circ} \mathrm{C}$ and sonicated on ice with constant stirring. The particulate fraction was pelleted by centrifugation at $4^{\circ} \mathrm{C}$ at $48,000 \mathrm{~g}$ for $30 \mathrm{~min}$. Preliminary experiments showed that approximately three-quarters of the protein kinase activity when assayed with exogenous substrates is in the supernatant fraction after this treatment. Higher yields of supernatant protein kinase activity (as much as twofold higher from equal amounts of platelets) were obtained when the platelets were frozen before sonication than when not frozen but sonicated immediately after isolation. The particulate fraction from platelets frozen before sonication still contained residual protein kinase activity when assayed with exogenous substrates.

Sodium dodecyl sulfate (SDS) polyacrylamide gel electrophoresis. Platelets to be fractionated by SDS polyacrylamide gel electrophoresis were solubilized by boiling for $5 \mathrm{~min}$ in 2-4\% SDS, $0.1 \mathrm{M}$ 2-mercaptoethanol, and $0.02 \mathrm{M}$ sodium phosphate buffer, $\mathrm{pH} 7.4$, ("SDS buffer"). After boiling in SDS buffer, the samples remained stable for over $30 \mathrm{~min}$ at room temperature and could be stored at $4^{\circ} \mathrm{C}$ for several hours or overnight at $-120^{\circ} \mathrm{C}$ as judged by comparison of the radiochromatograms of SDS gels of fresh and stored samples.

Cylindrical SDS polyacrylamide gel electrophoresis was performed essentially as described by Weber and Osborn (16). Bromphenol blue in $80 \%$ sucrose was added to samples of $5 \times 10^{7}$ solubilized platelets $(100 \mu \mathrm{g}$ protein $)$ which were layered on $5 \%$ polyacrylamide gels with $2.3 \%$ bisacrylamide and $0.1 \% \mathrm{SDS}$ in $0.1 \mathrm{M}$ sodium phosphate buffer, $\mathrm{pH} 7.4$, in 10 -cm-long, 5 -mm inside diameter glass tubes. Electrophoresis was carried out at $8 \mathrm{~mA} / \mathrm{gel}$ for 3.5 $\mathrm{h}$ with buffers of $0.1 \mathrm{M}$ sodium phosphate, $\mathrm{pH} 7.4,0.1 \%$ 
SDS containing $0.1 \mathrm{M}$ 2-mercaptoethanol. The gels were stained overnight in $12 \%$ trichloroacetic acid, $50 \%$ methanol, and $0.03 \%$ Coomassie Brilliant Blue $\mathrm{R}$ and subsequently destained by diffusion over $24 \mathrm{~h}$ in $7 \%$ acetic acid, $10 \%$ methanol, and $0.85 \%$ phosphoric acid. The gels were frozen and divided into $2-\mathrm{mm}$ slices with a razor blade type slicer (Bio-Rad Laboratories), and the slices were assayed for ${ }^{32} \mathrm{PO}_{4}$ in a liquid scintillation counter after the addition of Bray's solution (17).

SDS polyacrylamide slab gel electrophoresis was performed by a modification of the methods of Laemmli (18) and of Weber and Osborn (16) in an apparatus similar to that described by Reid and Bielski (19). The stacking and well-forming gel consisted of $3 \%$ acrylamide with $3.2 \%$ bisacrylamide and $0.1 \% \mathrm{SDS}$ in $0.05 \mathrm{M}$ sodium phosphate buffer, $\mathrm{pH}$ 6.4. The separating gel and the buffers were the same as described above for the cylindrical gels. Samples of $25-100 \mu \mathrm{g}$ platelet protein were layered onto the acrylamide in each of the 12 wells of a $2-\mathrm{mm}$ thick analytical slab gel. Electrophoresis was carried out at $30 \mathrm{~V}$ until the tracking dye had entered the separating gel and then at $60 \mathrm{~V}$ for $3 \mathrm{~h}$. Staining and destaining were performed as for cylindrical gels. The gels were dried on Whatman no. 50 hardened filter paper and exposed to Kodak RP Royal X-Omat medical X-ray film that was subsequently developed with a Kodak RPX-Omat developer. When indicated, the autoradiograph was scanned with a spectrophotometer equipped with linear transport and film holding accessories (Gilford Instrument Laboratories, Inc., Oberlin, Ohio).

Molecular weight determination by SDS polyacrylamide gel electrophoresis (16) employed the following standards: $E$. coli. $\beta$-galactosidase, 130,000 ; bovine fibrinogen alpha chain, 73,000 ; bovine serum albumin, 68,000 ; bovine fibrinogen beta chain, 60,000 ; bovine fibrinogen gamma chain, 53,$000 ; E$. coli alkaline phosphatase subunit, 43,000; rabbit muscle aldolase, 40,000 ; hog stomach mucosa pepsin, 35,000 ; the B chain of human $\alpha$-thrombin, 33,000; and sperm whale myoglobin, 17,200.

Partial purification of peak 7 protein by preparative SDS polyacrylamide gel clectrophoresis. $3 \mathrm{ml}$ of platelets containing $2 \times 10^{9}$ platelets $/ \mathrm{ml}$ were incubated with ${ }^{32} \mathrm{PO}_{4}$ as described above. Thrombin, $1 \mathrm{U} / \mathrm{ml}$, was added to the platelet suspension, and after a 5 -min incubation the platelets were solubilized in SDS buffer and the entire volume was electrophoresed in a single well of a $4-\mathrm{mm}$ thick SDS polyacrylamide slab gel. The protein in the region of the gel containing peak 7 protein was eluted as previously described (20) and adjusted to contain $10 \mathrm{mM}$ diisopropyl fluorophosphate (DFP). The solution was lyophilized, dissolved in $1 \mathrm{ml}$ of $\mathrm{H}_{2} \mathrm{O}$, and then dialyzed for $24 \mathrm{~h}$ with one change of dialysis fluid against $500 \mathrm{ml}$ of resuspension buffer containing $0.01 \%$ SDS. Single peaks of Coomassie Blue staining and radioactivity with the same mobility as peak 7 protein were seen on SDS polyacrylamide gel electrophoresis of this material, suggesting that it had remained intact during purification. Approximately $40 \%$ of peak 7 protein was recovered in the elution step.

Preparation of histone-Sepharose $4 B$. Histone-Sepharose was prepared as previously described (21) except that after coupling of the histone to the activated Sepharose, the histone-Sepharose was washed with 10 vol of $0.01 \mathrm{M}$ imidazole chloride, $1 \mathrm{M}$ sodium chloride $(\mathrm{pH} 6)$, then 10 vol of $0.01 \mathrm{M}$ imidazole chloride, $\mathrm{pH} 6$, and stored in the same buffer.

Histone-Sepharose affinity chromatography of crude platelet supernate. In a typical small-scale preparation, the supernate from platelets prepared from $2 \mathrm{U}$ fresh plateletrich plasma $\left(4 \mathrm{ml}, 2.88 \times 10^{5} \mathrm{U}\right.$ protein kinase activity) was diluted to $100 \mathrm{ml}$ with $0.01 \mathrm{M}$ imidazole chloride, $\mathrm{pH}$ 6 , and applied to a histone-Sepharose column (bed volume of $25 \mathrm{ml}$ ) that had previously been equilibrated with 0.01 $\mathrm{M}$ imidazole chloride, $\mathrm{pH}$ 6. After loading, the column was washed with $70 \mathrm{ml} 0.01 \mathrm{M}$ imidazole chloride, $\mathrm{pH} 6$, and the enzyme fractions were then eluted with a linear 0-0.6 $\mathrm{M} \mathrm{NaCl}$ gradient in $0.01 \mathrm{M}$ imidazole chloride, $\mathrm{pH} 6$ (total gradient volume was $240 \mathrm{ml}$ ). All steps were performed at $4^{\circ} \mathrm{C}$. $7-\mathrm{ml}$ fractions were collected. Protein kinase activity with protamine as substrate and cAMP binding activities were determined on each fraction, as described below. For a large-scale preparation, the supernate from platelets prepared from $150 \mathrm{U}$ 72-h-old platelet concentrates ( $158 \mathrm{ml}, 1.31 \times 10^{7} \mathrm{U}$ protein kinase activity) was diluted with 4 vol $0.01 \mathrm{M}$ imidazole chloride, $\mathrm{pH} 6$, and chromatographed on a 375-ml-bed volume histoneSepharose affinity column. The total gradient volume was 8 liters. Every fifth fraction (20 ml each) was assayed for protein kinase activity with protamine as substrate.

Pooled fractions of protein kinase after histone-Sepharose chromatography were concentrated by using a DEAEcellulose column equilibrated with $0.01 \mathrm{M}$ imidazole chloride, $\mathrm{pH} 6,\left(2.5 \times 3 \mathrm{~cm}\right.$ for up to $3 \times 10^{\circ} \mathrm{U}$ enzyme activity) at $4^{\circ} \mathrm{C}$. The enzyme fraction was loaded onto the column by diluting the histone-Sepharose fraction with 2 vol $0.01 \mathrm{M}$ imidazole chloride, $\mathrm{pH} 6$, in portions as they were applied to the column. After washing with the diluting buffer, the enzyme was eluted by washing the column with $0.01 \mathrm{M}$ imidazole chloride, $1 \mathrm{M} \mathrm{NaCl}, \mathrm{pH}$ 6. Fractions $(2 \mathrm{ml})$ were collected and analyzed for protein kinase activity. The peak tubes were pooled. This method usually gave a 10-15-fold concentration of activity with a recovery of approximately $80 \%$. No changes in the specific activity of the enzymes were observed.

Preparation of regulatory subunit from rabbit muscle protein kinase. Rabbit muscle cAMP-dependent protein kinase was prepared by a slight change in the modification (21) of a previously described (22) method. The method of Corbin et al. (21) was followed except that a histoneSepharose affinity column was used and the buffer was 0.01 $\mathrm{M}$ imidazole chloride- $0.001 \mathrm{M}$ EDTA, $\mathrm{pH}$ 6. Frozen rabbit muscle was used. The regulatory and catalytic subunits of this protein kinase were then separated by incubation with $\left[{ }^{3} \mathrm{H}\right]$ cAMP and chromatography on a histone-Sepharose column as described previously (23) where caseinSepharose was used. The regulatory subunit eluted after the catalytic subunit on this column.

Preparation of partially-purified, heat-stable inhibitor of cAMP-dependent protein kinases. The heat-stable inhibitor was prepared as previously described (24) from $1 \mathrm{lb}$ of frozen rabbit muscle. The purification was carried through the trichloroacetic acid precipitation step, subsequent resolubilization, and dialysis.

Determination of molecular weights by Sephadex G-150 chromatography. A $2.5 \times 61-\mathrm{cm}$ upward flow Sephadex G-150 column was calibrated by determining the elution volume $\left(V_{0}\right)$ of known molecular weight standards: rabbit muscle lactate dehydrogenase, 132,000; bovine serum albumin monomer, 69,$000 ;{ }^{125} \mathrm{I}$-ovalbumin, 45,000 ; ${ }^{125}$ I-diisopropyl phosphoryl-thrombin, 37,000; and sperm whale myoglobin, 17,800. Blue Dextran (mol wt $>2 \times 10^{8}$ ) was used to calculate the void volume $\left(V_{0}\right)$, and dinitrophenyl-glycine was utilized to calculate the included volume $\left(V_{i}\right)$. The proteins were monitored by their absorbance at $280 \mathrm{~nm}$ or by measuring their radioactivity. Dinitrophenyl-glycine was 
monitored at $410 \mathrm{~nm}$. The radioactive proteins were prepared by the chloramine-T method of Hunter (25). A standard curve was obtained by plotting $\log$ molecular weight vs. $\left(V_{0}-V_{0}\right) /\left(V_{i}-V_{0}\right)(26)$.

Protcin kinase assay. The standard reaction mixture contained in a total volume of $0.1 \mathrm{ml}: 0.05 \mathrm{M}$ Tris chloride (final $\mathrm{pH}=8.31$ ), $7 \mathrm{mM}$ magnesium acetate, $5 \mu \mathrm{M}$ cAMP (where added), $0.125 \mathrm{mM}\left[\gamma^{-32} \mathrm{P}\right] \mathrm{ATP}$ (sp act 5-30 cpm/ pmol), $5 \mathrm{mM}$ dithiothreitol, $0.1 \mathrm{mg}$ protamine or $0.1 \mathrm{mg}$ histone fraction $\mathrm{f}_{2 b}$ (Sigma Chemical Co.), and the enzyme to be assayed. In the study of the rabbit skeletal muscle enzyme, potassium phosphate $\mathrm{pH} 6.8$ was substituted for the Tris chloride. The reaction was initiated by the addition of enzyme and incubated for 5-20 min (depending on level of enzyme activity) at $37^{\circ} \mathrm{C}$. The reaction was terminated by adding $4 \mathrm{ml}$ of cold $20 \%$ (wt/vol) trichloroacetic acid and placing the tubes on ice for at least $10 \mathrm{~min}$. The samples were filtered through Gelman type GN-6 $(0.45-\mu \mathrm{m}$ pore size, $25-\mathrm{mm}$ diameter) filters with a Millipore 3025 manifold filtration system, and the precipitate was washed with two additional $4-\mathrm{ml}$ portions of cold $20 \%$ trichloroacetic acid (27). The filters and precipitates were dissolved in $10 \mathrm{ml}$ Bray's solution (17) and counted in a Packard Tri Carb liquid scintillation spectrometer (Packard Instrument Co., Inc., Downers Grove, Ill.). "1 U" of protein kinase activity was defined as the amount of enzyme that catalyzed the incorporation of $1 \mathrm{pmol}$ of ${ }^{32} \mathrm{PO}_{4}$ into protein in $1 \mathrm{~min}$. All assays were shown to be linear with respect to time and enzyme concentrations. The product of the protein kinase reaction was stable to boiling in $0.1 \mathrm{M}$ sodium phosphate, $\mathrm{pH} 7.4$, for $15 \mathrm{~min}$, which would be expected to exchange any noncovalently bound phosphate. Likewise, the product was labile to heating in $0.1 \mathrm{M}$ sodium hydroxide, suggesting the presence of a phosphomonoester linkage.

cAMP binding assay. cAMP binding was measured by a modification of the method of Walton and Garren (28). Saturating levels of $\left[{ }^{3} \mathrm{H}\right] \mathrm{cAMP}$ were used so that the assay was proportional to the amount of binding proteins.

Phosphodiesterase assay. Cyclic nucleotide $3^{\prime}, 5^{\prime}$-phosphodiesterase activity was measured by the method of Beavo et al. (29) except that Crotalus adamantcus venom was used as the source of $5^{\prime}$-nucleotidase and Dowex 1 was used to separate the nucleoside from the nucleotide. Incubations were at $37^{\circ} \mathrm{C}$ for $10 \mathrm{~min}$ and were terminated by boiling. Blank values were higher than those reported by B zavo et al. (29) in that $10-20 \%$ of the counts of $\left[{ }^{3} \mathrm{H}\right] \mathrm{cAMP}$ eluted in the Tris wash when no enzymes were added.

Misccllaneous methods. Platelet suspensions were disrupted by sonication for $15 \mathrm{~s}$ on ice with the microprobe of a Biosonik II sonifier set at $70 \%$ intensity for volumes less than $3 \mathrm{ml}$ and the standard probe under the same conditions for volumes greater than $3 \mathrm{ml}(15) .\left[{ }^{14} \mathrm{C}\right]$ Serotonin release studies were performed as previously described, the platelets having been incubated with $\left[{ }^{14} \mathrm{C}\right]$ serotonin before the phosphate depletion step (3). Alkaline and acid phosphatase were assayed as described by Lindhardt and Walter (30). Thrombin was assayed as described by Seegers and Smith (31). Protein was estimated by the method of Lowry et al. (32).

\section{RESULTS}

Effect of thrombin on protein phosphorylation in intact platelets. In preliminary experiments we determined that the prolonged period required for phosphate depletion

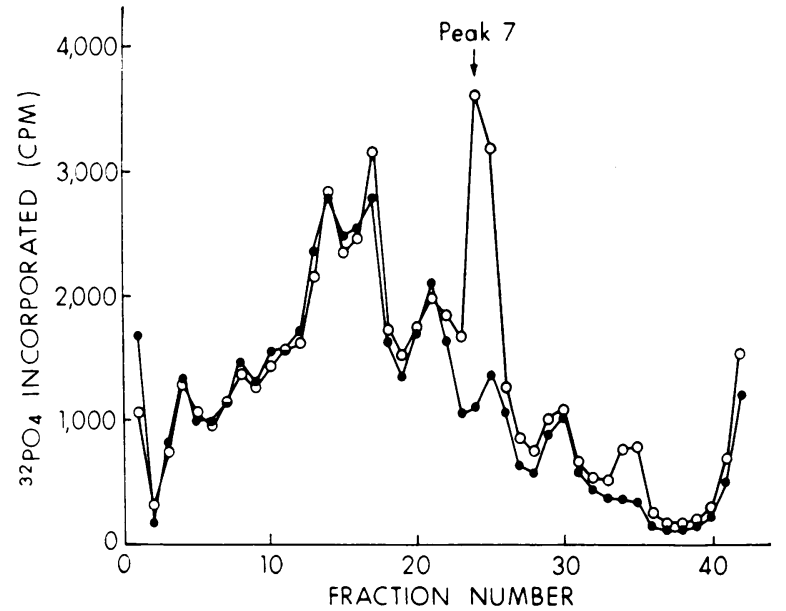

FigURE 1 SDS polyacrylamide gel radiochromatogram of the effect of thrombin on platelet protein phosphorylation. Platelets were loaded with ${ }^{32} \mathrm{PO}_{4}(0.5 \mathrm{mCi} / \mathrm{ml})$ as described in the text and then electrophoresed on SDS polyacrylamide gels. $(\bullet){ }^{32} \mathrm{PO}_{4}$ incorporation into control platelets; $(O)$ ${ }^{32} \mathrm{PO}_{4}$ incorporation into platelets treated with thrombin, $1 \mathrm{U} / \mathrm{ml}$, for $5 \mathrm{~min}$.

(two 15-min incubations) and subsequent loading with ${ }^{32} \mathrm{PO}_{4}$ did not damage the platelets with respect to their ability to undergo thrombin-induced $\left[{ }^{14} \mathrm{C}\right]$ serotonin release. Shorter periods of phosphate depletion or loading diminished the incorporation of ${ }^{32} \mathrm{PO}_{4}$ into platelet proteins. While we refer to this process as "phosphate loading," we do not know what changes, if any, occur in intracellular phosphate. Rather, these conditions are those that we found to result in maximal protein labeling in control platelets.

There was prominent protein phosphorylation observed in control ${ }^{32} \mathrm{PO}_{4}$-loaded platelets as shown in the radiochromatogram of the cylindrical SDS polyacrylamide gel shown in Fig. 1. 9 radioactive peaks were consistently seen in radiochromatograms of cylindrical gels, while approximately 20 radioactive proteins could be distinguished in the autoradiographs of SDS polyacrylamide slab gels. The increased number of radioactive proteins seen with the latter technique is due to the increased resolution of radioactivity seen on autoradiographs as compared to sliced gels counted in a liquid scintillation counter. When ${ }^{32} \mathrm{PO}_{4}$-loaded platelets were treated with thrombin, $1 \mathrm{U} / \mathrm{ml}$, for $5 \mathrm{~min}$ before boiling in SDS buffer, a different pattern of ${ }^{23} \mathrm{PO}_{4}$ incorporation was observed. Either bovine or human thrombin induced a 2-6-fold increase (mean 3.28-fold $\pm 0.27 \mathrm{SEM}, n=13$ ) in phosphate incorporation into a peak of ${ }^{32} \mathrm{PO}_{4}$ corresponding to the darkest staining protein band on the SDS polyacrylamide gel. This protein had an apparent molecular weight of 40,000 and was designated "peak 7." A similar increase in phosphorylation (2.84-fold \pm 0.4 


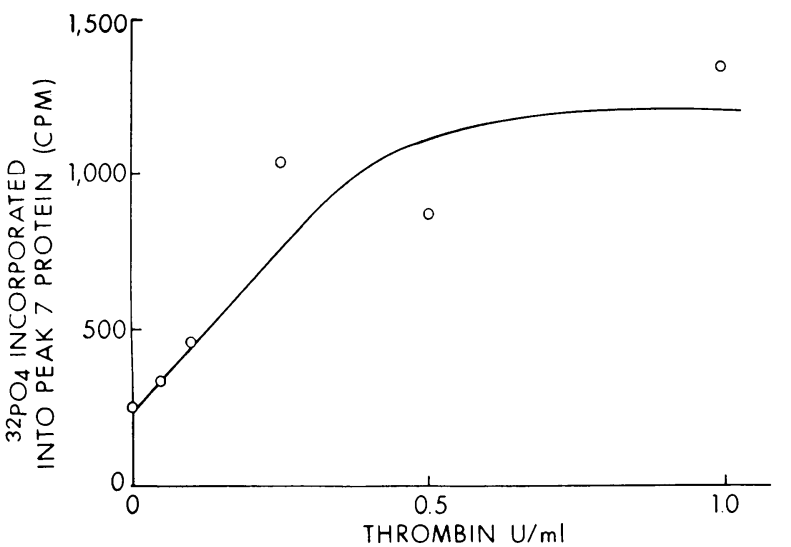

Figure 2 Effect of increasing concentrations of thrombin on ${ }^{32} \mathrm{PO}_{4}$ incorporation into peak 7 protein. ${ }^{32} \mathrm{PO}_{4}$-loaded platelets were incubated with various thrombin concentrations for $5 \mathrm{~min}$ at room temperature before the platelets were solubilized and electrophoresed on cylindrical SDS polyacrylamide gels as described in Methods. The radioactivity in each peak was calculated by summing the counts per minute of the three highest fractions in the peak.

SEM, $n=9$ ) was consistently seen in a peak of approximately 20,000 mol wt designated "peak 9." There was no consistent thrombin-induced alteration of ${ }^{32} \mathrm{PO}_{4}$ incorporation into radioactive peaks other than 7 and 9 when the radioactive peaks were examined by either cylindrical or slab SDS polyacrylamide gel electrophoresis. In contrast, thrombin that was inhibited by DFP at its active serine residue, had no effect on the incorporation of ${ }^{32} \mathrm{PO}$ into platelet protein.

To examine the possibility that release-inducing agents other than thrombin could initiate platelet protein phosphorylation, we studied the effects of E-PHA $(14,33)$ on platelets. Exposure of ${ }^{32} \mathrm{PO}_{4}$-loaded platelets to $\mathrm{E}$ PHA $(0.13 \mathrm{mg} / \mathrm{ml}$ for $15 \mathrm{~min})$ resulted in a 3.2 -fold and 3.9-fold increase in phosphorylation of peak 7 and 9 proteins, respectively.

Characterization of peak 7 and peak 9 protein. We initially demonstrated that the radioactivity in peak 7 was covalently bound to protein. ${ }^{32} \mathrm{PO}_{4}$-loaded platelets were precipitated with cold $10 \%$ trichloroacetic acid and then delipidated as described by Cohen et al. (34). The SDS polyacrylamide gel Coomassie Blue staining and radiochromatogram patterns of the material remaining after lipid extraction were similar to those described above for whole solubilized platelets, suggesting that the radioactivity in peaks 7 and 9 is not associated with phospholipids. When samples of the delipidated trichloroacetic acid precipitate from thrombin-treated platelets were boiled for $15 \mathrm{~min}$ in $0.2 \mathrm{M}$ sodium hydroxide we found a $90 \%$ loss of ${ }^{32} \mathrm{PO}_{4}$ as measured by trichloroacetic acid precipitation. In contrast, treatment in $10 \%$ trichloroacetic acid for $15 \mathrm{~min}$ at $90^{\circ} \mathrm{C}$ resulted in only $8 \%$ hydrolysis of ${ }^{32} \mathrm{PO}_{4}$. These results are consistent with the stability of phosphomonoesters of serine and threonine (35) and indicate that the phosphate is not incorporated into RNA, which is labile in hot acid (36). Partial acid hydrolysis of ${ }^{32} \mathrm{PO}_{4}$-labeled delipidated platelet protein followed by high voltage paper electrophoresis (37) disclosed the presence of labeled phosphoserine and phosphothreonine residues. When corrected for hydrolysis of phosphoserine and phosphothreonine (37), over $80 \%$ of the label was determined to be in the form of phosphoserine.

When peak 7 protein, eluted from a 4-mm thick SDS polyacrylamide gel as described in Methods, was treated with hot alkali or hot acid, results similar to those described above for the delipidated platelet protein were observed. Treatment of peak 7 protein with TPCK trypsin $(0.3 \mathrm{mg} / \mathrm{ml})$ for $21 \mathrm{~h}$ at $37^{\circ} \mathrm{C}, \mathrm{pH} 7.4$, resulted in a $63 \%$ decrease in radioactivity in peak 7 protein and a similar decrease in Coomassie Blue staining upon re-electrophoresis of the protein on SDS gels. Incubation of peak 7 protein for $15 \mathrm{~h}$ at $45^{\circ} \mathrm{C}, \mathrm{pH} 8.0$, with E. coli alkaline phosphomonoesterase, $7 \mathrm{U} / \mathrm{ml}$, resulted in $78 \%$ loss of radioactivity from peak 7 protein as determined by re-electrophoresis of the protein on SDS gels.

Treatment of the delipidated platelet protein with sodium hydroxide or alkaline phosphatase as described above resulted in a 65 and $73 \%$ decrease, respectively, in radioactivity in peak 7 protein as assessed by subsequent SDS polyacrylamide gel electrophoresis of the samples. These experiments indicate that the radioactivity in peak 7 and peak 9 is in the protein in the form of phosphomonoesters of serine and threonine residues.

Effect of thrombin concentration on peak 7 protein and peak 9 protein phosphorylation. The effect of thrombin on peak 7 protein and peak 9 protein phosphorylation was dependent upon thrombin concentration. The thrombin concentration that produced half-maximal phosphorylation was $0.25 \mathrm{U} / \mathrm{ml}$ for both peak 7 protein (Fig. 2) and peak 9 protein.

Time-course of thrombin-induced peak 7 protein and peak 9 protein phosphorylation. Thrombin had no effect on the phosphorylation of peak 7 protein or peak 9 protein when platelets were disrupted before thrombin treatment (see below). Thus, by lysing the platelets with SDS, we were able to stop the interaction between platelets and thrombin rapidly, allowing us to determine the time-course of the effect of thrombin on peak 7 and peak 9 protein phosphorylation. The effect of thrombin, $1 \mathrm{U} / \mathrm{ml}$, was rapid with the time for half-maximal phosphorylation of peak 7 protein being $10 \mathrm{~s}$ (Fig. 3). The time for half-maximal phosphorylation of peak 9 protein (14 s) was similar (data not shown).

The thrombin concentration curve and the time-course for thrombin-induced phosphorylation of peak 7 and 
peak 9 proteins were similar to those parameters previously observed for the thrombin-induced platelet release reaction and for the inhibition of platelet adenylate cyclase by thrombin $(5,33,38,39)$.

Effect of raising intracellular $c A M P$ concentrations on phosphorylation of peak 7 and 9 proteins. $\mathrm{PGE}_{1}$, $1 \mu \mathrm{g} / \mathrm{ml}$, and $N^{6}-2^{\prime}, 0^{\prime}$-dibutyryl cAMP (DB-cAMP), $1 \mathrm{mM}$, compounds that raise the intracellular cAMP levels in platelets (2) and partially block the thrombininduced release reaction $(5,40)$, did not alter platelet protein phosphorylation significantly in the absence of thrombin. However, treatment of intact platelets with these agents before the addition of thrombin resulted in a 48 and $53 \%$ inhibition, respectively, of peak 7 protein phosphorylation, as estimated from densitometry of the autoradiographs as described in Methods. Similarly, thrombin-induced peak 9 protein phosphorylation was inhibited 55 and $70 \%$ by $\mathrm{PGE}_{1}$ and DB-cAMP, respectively. The inhibition of thrombin-induced peak 7 and peak 9 protein phosphorylation by $\mathrm{PGE}_{1}$ and DB-cAMP is shown in Fig. 4.

Molecular weight of peak 7 protein by gel filtration. Platelets $\left(70 \mathrm{ml}\right.$ of $4 \times 10^{\circ}$ platelets $\left./ \mathrm{ml}\right)$ were isolated from $10 \mathrm{U}$ of 72 -h-old platelet concentrates, loaded with $0.02 \mathrm{mCi} / \mathrm{ml}^{32} \mathrm{PO}_{4}$, and treated with $4 \mathrm{U} / \mathrm{ml}$ thrombin. These platelets retained the ability to aggregate and to release $\left[{ }^{14} \mathrm{C}\right]$ serotonin when exposed to thrombin. The platelets were sedimented, and the supernate was discarded before sonication of the platelets in $12.5 \mathrm{ml}$ $0.1 \mathrm{~m} . \mathrm{M}$ sodium phosphate buffer, $\mathrm{pH} 7.4$, containing $10 \mathrm{mM}$ DFP. The particulate material was sedimented at $165,000 \mathrm{~g} \times 60 \mathrm{~min}$ at $4^{\circ} \mathrm{C}$, and $100 \mathrm{mg}$ of the supernatant protein in $10 \mathrm{ml}$ (containing $75 \%$ of the total platelet peak 7 protein) was chromatographed at $4^{\circ} \mathrm{C}$ in $0.1 \mathrm{M}$ sodium phosphate buffer, $\mathrm{pH} 7.4$, on a calibrated Sephadex G-150 column as described in Methods.

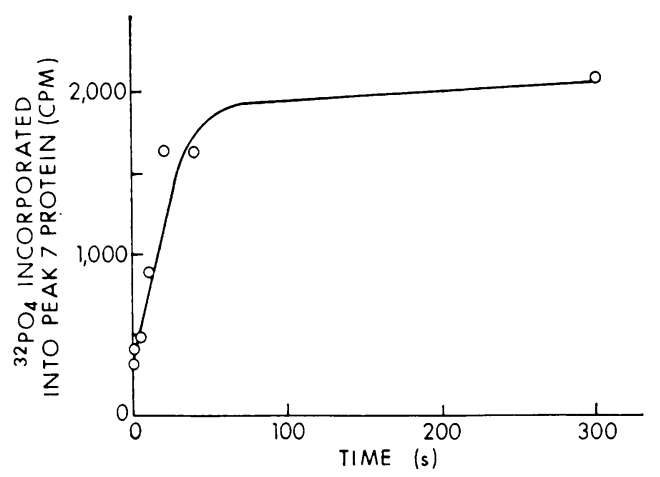

Figure 3 Time-course of the effect of thrombin on the phosphorylation of peak 7 protein. ${ }^{32} \mathrm{PO}_{4}$-loaded platelets were incubated with thrombin $(0.76 \mathrm{U} / \mathrm{ml})$ for various times before the reaction was stopped by solubilizing the platelets in SDS. ${ }^{32} \mathrm{PO}_{4}$ incorporated by peak 7 protein was estimated as described in Fig. 2.

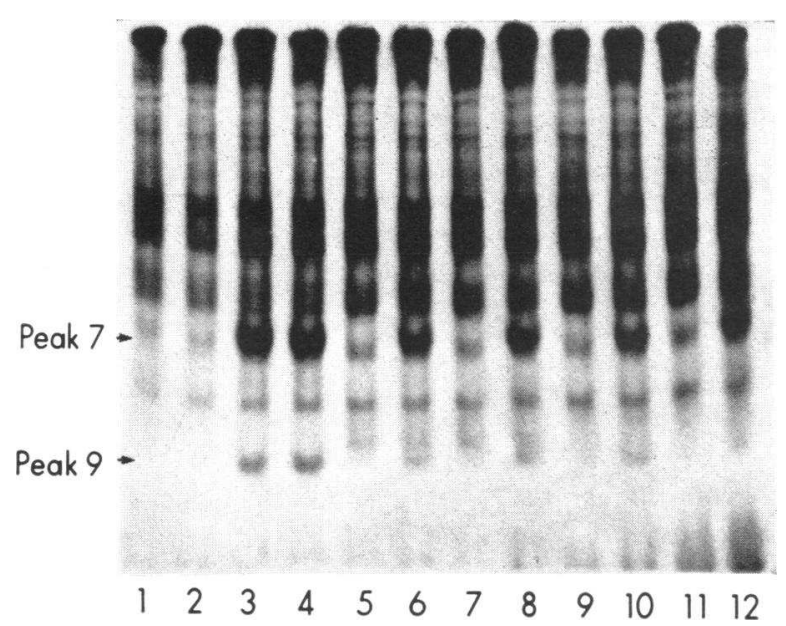

FIGURE 4 Autoradiograph of an SDS polyacrylamide slab gel electrophoresis showing the effect of $\mathrm{PGE}_{1}(1 \mu \mathrm{g} / \mathrm{ml})$ or DB-cAMP $(1 \mathrm{mM})$ on platelet protein phosphorylation. Platelets were loaded with ${ }^{32} \mathrm{PO}_{4}(0.5 \mathrm{mCi} / \mathrm{ml})$ as described in Methods. Gols 1 and 2: no additions; 3 and 4: thrombin, $1 \mathrm{U} / \mathrm{ml}$, for $5 \mathrm{~min} ; 5$ and $7: \mathrm{PGE}_{1}$ alone for $20 \mathrm{~min}$; 6 and 8: $\mathrm{PGE}_{1}$ for $15 \mathrm{~min}$ with the addition of thrombin, $1 \mathrm{U} / \mathrm{ml}$, for a further $5 \mathrm{~min} ; 9$ and 11: DB-cAMP alone for $20 \mathrm{~min}$; 10 and 12: DB-cA.MP for $15 \mathrm{~min}$ with the addition of thrombin, $1 \mathrm{U} / \mathrm{ml}$, for a further $5 \mathrm{~min}$. The radioactivity in peak 7 and 9 proteins was assessed from the $A_{500}$ of the bands on the autoradiograph of an SDS slab gel electrophoresis of the fractions. The peak absorbance of each band was less than 2.0. At these levels the peak absorbance of each band was proportional to the radioactivity of the same band on the SDS polyacrylamide gel as assessed in a liquid scintillation spectrometer.

Three peaks of radioactivity were eluted from the column. The first peak was detected at the void volume, while the third peak eluted just ahead of the included volume. The second peak of radioactivity eluting from the column, subsequently identified as containing peak 7 protein by SDS polyacrylamide gel electrophoresis of the fractions, had an apparent molecular weight of 49,000 . This value is similar to the molecular weight of peak 7 protein determined by SDS polyacrylamide gel electrophoresis. Furthermore, the apparent molecular weight of the radioactive protein in peak 7 as determined by SDS polyacrylamide gel electrophoresis was not altered by mercaptoethanol reduction. This suggests that peak 7 protein does not have covalently bound subunits.

Platelet protein kinase activity. In preliminary experiments we demonstrated that platelet sonicates contained significant protein kinase activity when assayed by using exogenous substrates. ${ }^{2}$ Endogenous phosphoryla-

${ }^{2}$ Protein kinase activity assayed with exogenous substrates refers to incorporation of ${ }^{32} \mathrm{PO}_{4}$ into trichloroacetic acid-precipitable material as described in Methods when protein acceptors (e.g., protamine or histone $f_{2 b}$ ) are added. Endogenous phosphorylation is incorporation of ${ }^{32} \mathrm{PO}_{4}$ into trichloroacetic acid-precipitable material when assayed with no added protein acceptors. 
TABLE I

Relative Phosphorylation of Peak 7 Protein in Disrupted Platelets

\begin{tabular}{|c|c|c|c|c|c|}
\hline \multirow[b]{2}{*}{ Gel } & \multirow[b]{2}{*}{ Whole sonicates } & \multirow[b]{2}{*}{$\begin{array}{l}\text { Supernatant } \\
\text { fraction }\end{array}$} & \multirow[b]{2}{*}{$\begin{array}{l}\text { Thrombin }(1 \mathrm{U} / \mathrm{ml}) \\
\text { during labeling }\end{array}$} & \multirow[b]{2}{*}{$\begin{array}{l}\text { CAMP }(1 \mu \mathrm{M}) \\
\text { during labeling }\end{array}$} & \multirow{2}{*}{$\frac{\begin{array}{c}\text { Ratio } \\
\text { peak } 7 \text { radioactivity }\end{array}}{\text { peak } 7 \text { protein }}$} \\
\hline & & & & & \\
\hline 1 & + & - & - & - & 2.1 \\
\hline 2 & + & - & - & + & 2.3 \\
\hline 3 & + & - & + & - & 2.2 \\
\hline 4 & + & - & + & + & 2.0 \\
\hline 5 & - & + & - & - & 3.5 \\
\hline 6 & - & + & - & + & 3.3 \\
\hline 7 & - & + & + & - & 3.4 \\
\hline 8 & - & + & + & + & 3.3 \\
\hline
\end{tabular}

Platelet samples $\left(4 \times 10^{9} / \mathrm{ml}\right)$ were sonicated and centrifuged to obtain the supernatant fraction where indicated. Endogenous phosphorylation was measured by incubation with $125 \mu \mathrm{M}\left[\gamma-{ }^{32} \mathrm{P}\right] \mathrm{ATP}$ $(244 \mu \mathrm{Ci} / \mathrm{mol}), 5 \mathrm{mM}$ magnesium acetate- $0.5 \mathrm{mM}$ 1-methyl-3-isobutylxanthine for $10 \mathrm{~min}$ at $22^{\circ} \mathrm{C}$. $10-\mu$ l portions of each reaction mixture were subjected to SDS polyacrylamide slab gel electrophoresis. Autoradiograph film exposure $7 \mathrm{~h}$.

The autoradiograph and a negative photograph of the stained gel were scanned at $500 \mathrm{~nm}$ in a Gilford spectrometer as described in Methods. Units are peak absorbance at $500 \mathrm{~nm}$ as described in the legend of Fig. 4. Results are expressed as the ratio of peak absorbance on the autoradiograph/peak absorbance of a negative photograph of the stained gel.

tion amounted to less than $5 \%$ of the total activity and has been subtracted in all activities determined with exogenous substrates reported hereafter. Crude sonicates of fresh platelets contained protein kinase activity that was only slightly stimulated by added cAMP when assayed with protamine as substrate (1.1-1.2-fold) and was stimulated 1.5-fold when histone $f_{2 b}$ was used as substrate. After centrifugation at $48,000 \mathrm{~g}$ for $30 \mathrm{~min}$, $65-75 \%$ of the total protein kinase activity remained in the supernatant fraction, and the cAMP dependence remained unchanged. We attempted to alter either the level of activity or degree of cAMP stimulation in the crude sonicates or supernatant fraction by treating platelets with thrombin, $1 \mathrm{U} / \mathrm{ml}$, before sonication. There was no observed change in total protein kinase activity or ratio of activity -cAMP/+cAMP despite the presence of the phosphodiesterase inhibitor 1-methyl-3-isobutylxanthine with either protein substrate (41). Similar experiments using adipose tissue have demonstrated hormone-induced alterations in the state of activation of protein kinases (41). In experiments where platelets were incubated with $\mathrm{PGE}_{1}$ for 20 min before sonication, the total amount of exogenous protein kinase activity with each substrate was unchanged, but the activity in the absence of cAMP with histone $f_{2 b}$ as substrate was elevated 1.6-fold, suggesting that if there had been a change in the degree of cAMP stimulation of protein kinase activity by thrombin, our method could have detected it.

Endogenous phosphorylation of crude platelet extracts. When the endogenous phosphorylation activities of soni- cated platelets and the supernatant fraction of sonicated platelets were studied using higher specific activity $\left[\gamma_{-}{ }^{32} \mathrm{P}\right]$ ATP $(200-1,000 \mathrm{cpm} / \mathrm{pmol})$, we found no change in total incorporation of label into trichloroacetic acid-precipitable material with or without $1 \mathrm{U} / \mathrm{ml}$ bovine thrombin present during the labeling period. When the samples were electrophoresed on an SDS slab gel, an autoradiograph showed most of the label was contained in peak 7 and 9 proteins, and no significant change in labeling pattern was observed when thrombin was added during labeling. Likewise, addition of $1 \mu \mathrm{M}$ cAMP in the presence of the phosphodiesterase inhibitor 1-methyl3 -isobutylxanthine with or without $1 \mathrm{U} / \mathrm{ml}$ thrombin showed no difference in incorporation of ${ }^{32} \mathrm{PO}_{4}$ into trichloroacetic-precipitable material. The autoradiograph also showed no significant change in labeling pattern. There was a slight decrease in phosphorylation of peak 7 and 9 proteins when platelets were treated with thrombin before disruption and measurement of endogenous phosphorylation (data not shown). This result could be explained by increased saturation of protein substrates due to phosphorylation induced by thrombin before disruption; however, we have no direct evidence to support this hypothesis.

In experiments without the phosphodiesterase inhibitor, identical results were obtained, indicating that despite the high levels of phosphodiesterase in platelets (370 pmol cAMP hydrolyzed/min per $10^{\circ}$ platelets) cAMP does not appear to regulate endogenous phosphorylation in crude extracts of disrupted platelets. Table I shows results of experiments in which the 
labeling was carried out by using either the whole sonicated platelet fraction or the supernatant fraction from sonicated platelets. The lower labeling of peak 7 protein in the whole sonicate compared to the separated supernatant fraction cannot be explained simply. The particulate fraction may inhibit phosphorylation or contain phosphoprotein phosphatases. When the separated particulate fraction was incubated with $\left[\gamma_{-}{ }^{32} \mathrm{P}\right] \mathrm{ATP}$, no significant labeling was observed on the autoradiograph. When the whole platelet sonicate was labeled and then separated into supernatant and particulate fractions and electrophoresed, approximately $10-15 \%$ of the label appearing in peaks 7 and 9 was located in the particulate fraction. The labeling pattern of the supernatant fraction upon electrophoresis was identical to that obtained when the separated supernatant fraction was labeled. Thus, $(a)$ the particulate fraction contains very little protein kinase but some substrate, $(b)$ the particulate fraction does not contain additional protein kinase(s) that phosphorylate additional supernatant proteins, and (c) the supernatant fraction contains protein kinase plus the peak 7 and 9 protein substrates.

Platelet protein kinase fractionation on histoneSepharose. In an attempt to characterize the protein kinase enzymes in the platelet supernatant fraction, we chromatographed this material on histone-Sepharose as described in Methods. A typical elution pattern of a small-scale preparation (crude supernate prepared from $2 \mathrm{U}$ of platelet-rich plasma) is shown in Fig. 5. Parallel

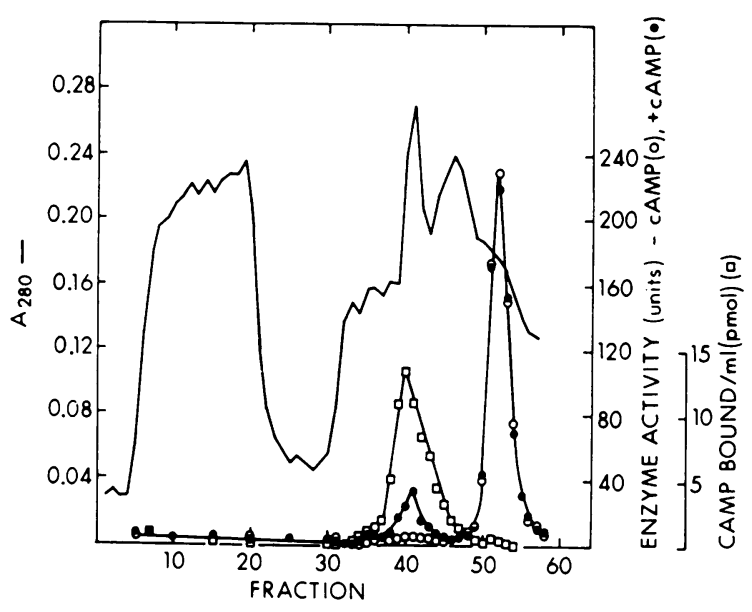

FIGURE 5 Elution pattern of protein kinase activity of crude platelet supernate from histone-Sepharose affinity column. Supernate from platelets prepared from 2 U platelet-rich plasma was chromatographed as described in Methods. (๑) Protein kinase activity in the presence of cAMP with protamine as substrate; $(O)$ protein kinase activity in the absence of cAMP with protamine as substrate; ( $\square)\left[{ }^{3} \mathrm{H}\right]$ cAMP binding activity; the solid line is absorbance at $280 \mathrm{~nm}$. The sodium chloride gradient was begun at fraction 27 .
TABLE II

firactionation of Iluman Platelet P'rolein Kinuses

\begin{tabular}{|c|c|c|c|}
\hline \multirow[b]{2}{*}{ Crude supernatant prepared from: } & \multicolumn{2}{|c|}{ Protein kinase activity } & \multirow{2}{*}{$\begin{array}{l}\text { cAMP } \\
\text { binding } \\
\text { activity }\end{array}$} \\
\hline & Total & Spact & \\
\hline & $U$ & $U / m y$ prolein & pmol \\
\hline $\begin{array}{l}2 \mathrm{U} 72 \text {-h-old platelet } \\
\text { concentrates }\end{array}$ & $\begin{array}{l}4.5 \times 10^{5+} \\
2.0 \times 10^{5 *}\end{array}$ & $\begin{array}{l}8,385_{+}^{+} \\
3,719^{*}\end{array}$ & 468 \\
\hline cAMP-dependent enzyme & $\begin{array}{l}1.5 \times 10^{5+} \\
3.2 \times 10^{4 *}\end{array}$ & $\begin{array}{l}9.846_{+}^{+} \\
2,146^{*}\end{array}$ & 262 \\
\hline cAMP-independent enzyme & $\begin{array}{l}2.7 \times 10^{1+} \\
4.4 \times 10^{4 *}\end{array}$ & $\begin{array}{r}8.2 .39_{+}^{+} \\
13,4.39^{*}\end{array}$ & 13 \\
\hline
\end{tabular}

Protein kinase activities in the presence of cAMP are expressed in units at pH 8.3 with protamine as substrate $\left(^{*}\right)$ or histone $f_{2 b}$ as substrate $\left(\begin{array}{l}+ \\ )\end{array}\right)$ as described in Methods. cAMP binding was measured at $\mathrm{pH} 8.4$ as described in Methods.

experiments with platelets treated with thrombin before sonication showed an essentially identical chromatogram. The two enzyme fractions were designated "cA.MP-dependent" and "cAMP-independent," referring to the earlier (at low salt) and later (at higher salt) eluting peaks, respectively. Initially, protamine was used as a screening substrate to monitor column elution. Since the preferential substrate for the cAMP-dependent enzyme was histone $f_{2 b}$, an experiment was performed in which both protamine and histone $f_{2 b}$ in the presence of cAMP were used as substrates in analyzing a histoneSepharose affinity column. The same two enzyme fractions were found as in Fig. 5, with the relative peak enzyme activities reversed with the two substrates (i.e., with histone $f_{2 b}$ as substrate, the major peak was the cAMP-dependent enzyme fraction; with protamine as substrate, the cAMP-independent enzyme was the larger peak). A summary of enzyme activities recovered for a typical small-scale experiment is shown in Table II. The true recoveries of the enzyme activities are greater than the values shown since approximately $20 \%$ more activity was in the region between the two peaks which was not pooled because of overlap of the two enzymes. In a large-scale experiment requiring $24 \mathrm{~h}$ to complete, only about $\frac{1}{3}-\frac{1}{2}$ of the total protein kinase activity was recovered after histone-Sepharose chromatography. Smaller-scale experiments generally gave higher yields since they could be completed within a few hours. Storage of portions of the crude extracts or separated enzyme fractions at $4^{\circ} \mathrm{C}$ for $24 \mathrm{~h}$ resulted in loss of up to $\frac{2}{3}$ of protein kinase activity, suggesting that the poor recovery in large-scale experiments may result from enzyme inactivation during fractionation.

Further studies and purification of these enzymes have proved difficult due to their instability. Thus, neither enzyme could be concentrated by Amicon ultrafiltration. Overnight dialysis against a variety of buffers resulted in approximately 50\% inactivation of the cA.MP-dependent enzyme and over $90 \%$ inactivation of the 


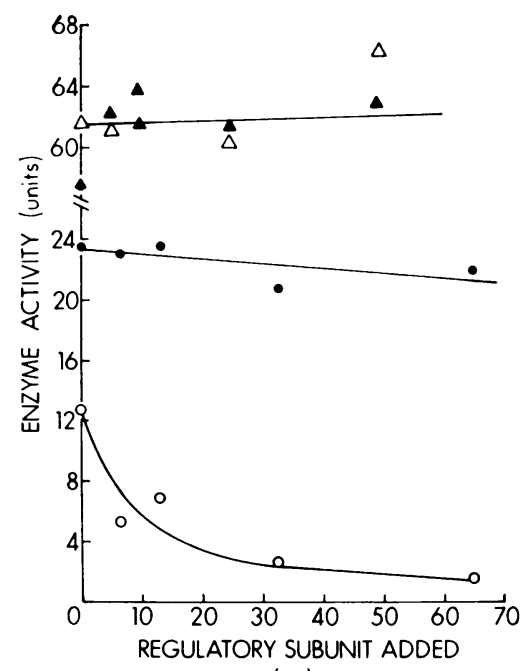

(jg)

Figure 6 Effect of rabbit muscle regulatory subunit on the platelet cAMP-dependent and cAMP-independent enzymes in the presence and absence of cAMP. The assays were performed as described in Methods except that the enzymes were incubated with the indicated amount of regulatory subunit for $30 \mathrm{~min}$ at $0^{\circ} \mathrm{C}$ before initiating the protein kinase assay. Protamine was the substrate with the cAMP-independent enzyme and histone $f_{2 b}$ was the substrate with the cAMP-dependent enzyme. (O) cAMPdependent enzyme in the absence of cAMP; $(\bullet)$ cAMPdependent enzyme in the presence of cAMP; $(\triangle)$ and $(\Delta)$ cAMP-independent enzyme in the absence and presence of cAMP, respectively.

cAMP-independent enzyme. Numerous attempts to stabilize the enzymes proved unsuccessful although they were more stable after concentration on small DEAE-cellulose columns (see Methods).

Characterization of platelet protein kinases with rabbit muscle proteins. Experiments using rabbit muscle regulatory subunit and rabbit muscle heatstable inhibitor were carried out to establish that the cAMP-dependent enzyme was a typical cAMPregulated protein kinase and also to determine whether the cAMP-independent enzyme was the free catalytic subunit of a cAMP-regulated holoenzyme. In the presence of the rabbit muscle regulatory subnuit, the cAMPdependent enzyme was inhibited in the absence of cAMP but was unaffected in the presence of CAMP as shown in Fig. 6. This result suggests that this enzyme is a cAMPdependent holoenzyme. This conclusion was further supported by results shown in Fig. 7, where inhibition by rabbit muscle heat-stable inhibitor in the presence and to some extent in the absence of cAMP is demonstrated. In contrast, the cAMP-independent enzyme does not apparently correspond to the catalytic subunit of the cAMP-regulated enzyme. Thus, it is not inhibited by regulatory subunit (Fig. 6) nor is it inhibited by the heat-stable inhibitor (Fig. 7). The apparent stimulation of this protein kinase by the relatively crude preparation of heat-stable inhibitor is not due to the inhibitor's acting as a substrate since there was no increased ${ }^{32} \mathrm{PO}_{4}$ incorporated into trichloroacetic acid-precipitable material when protamine (protein acceptor) was omitted from the reaction mixture.

Effect of thrombin on the activity of the platelet protein kinases. When we incubated both separated enzyme fractions with varying concentrations of thrombin (0.1$10 \mathrm{U} / \mathrm{ml}$ ) for varying periods of time $(1-60 \mathrm{~min})$ at room temperature, we observed no alteration of activity or change in cAMP dependence when assayed with exogenous substrates in any of these experiments when comparing thrombin-treated to untreated enzyme.

Properties of platelet protein kinases. The platelet protein kinases were unlike in their lability upon heating of the DEAE-concentrated enzymes $(6,000 \mathrm{U} / \mathrm{ml})$ at $37^{\circ} \mathrm{C}$. Thus, the cAMP-dependent enzyme lost $30 \%$ of its activity after $1 \mathrm{~h}$ while the cAMP-independent enzyme lost $85 \%$ of its activity. Both enzymes require $\mathrm{Mg}^{++}$for activity, and neither enzyme showed any activity when $\mathrm{Ca}^{++}$was the only divalent cation present. In the presence of $7 \mathrm{mM} \mathrm{Mg}^{++}$ions, calcium markedly inhibited protein kinase activity with $50 \%$ inhibition of activity of both enzymes occurring at $1-2 \mathrm{mM} \mathrm{Ca}^{++}$.

The platelet protein kinase enzymes were also readily

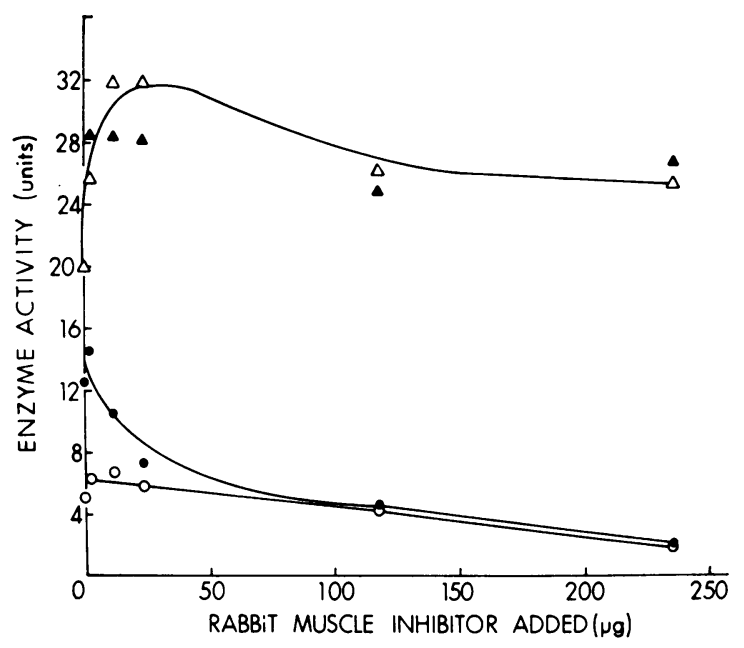

Figure 7 Effect of rabbit muscle heat-stable protein on the platelet cAMP-dependent and cAMP-independent enzymes in the presence and absence of cAMP. The assays were performed as described in Methods except that the enzymes were incubated with the indicated amount of inhibitor at $37^{\circ} \mathrm{C}$ for $10 \mathrm{~min}$ before initiating the protein kinase assay. The cAMP-dependent enzyme was assayed with histone $\mathrm{f}_{2 b}$ as substrate and the cAMP-independent enzyme with protamine as substrate. (O) cAMP-dependent enzyme in the absence of cAMP; (•) cAMP-dependent enzyme in the presence of cAMP; $(\triangle)$ and $(\Delta)$ cAMPindependent enzyme in the absence and presence of cAMP, respectively. 
distinguished by substrate specificity as can be seen in Table II. Thus, the cAMP-dependent enzyme was most active with histone $f_{2 b}$ as substrate while the cAMPindependent enzyme was less active using this substrate with protamine being the preferred substrate. Because the substrate specificities were so different, it is highly improbable that the cAMP-independent enzyme is the free catalytic subunit of the cAMP-dependent enzyme, supporting the evidence shown with the rabbit skeletal muscle inhibitors (Figs. 6 and 7 ).

When $\left[\gamma^{32} \mathrm{P}\right] \mathrm{GTP}$ was used as the phosphate donor in place of ATP, there was no activity with either enzyme. Neither enzyme fraction contained any acid phosphatase activity. When assayed for cAMP-phosphodiesterase activity, both enzyme fractions showed activity that was sufficient to destroy only $5-10 \%$ of the cAMP during a standard protein kinase assay. Thus, the lack of stimulation by cAMP of the cAMPindependent enzyme was not due to destruction of the cAMP by a phosphodiesterase present in the protein kinase fraction.

Endogenous phosphorylation using fractionated protein kinases. Since the two enzyme fractions were relatively crude preparations, we studied their endogenous phosphorylation with high specific activity $\left[\gamma_{-}{ }^{32} \mathrm{P}\right]$ ATP $(200-1,000 \mathrm{cpm} / \mathrm{pmol})$. The cAMP-dependent enzyme showed increased incorporation of label into trichloroacetic acid-precipitable material when cAMP was added. When the reaction product was electrophoresed on an SDS polyacrylamide slab gel and an autoradiograph was obtained, cAMP-stimulated incorporation of label into a protein of mol wt 98,000 was seen. Incorporation of label into a protein that coelectrophoresed with peak 7 protein was also observed, and this incorporation was increased twofold when $2 \mu \mathrm{M}$ cAMP was added (data not shown). This result is paradoxical in that the thrombin-induced phosphorylation reaction in intact platelets is inhibited by agents that increase intracellular cAMP. There was no ${ }^{32} \mathrm{PO}_{4}$ label in the region of the gel corresponding to peak 9 protein. Whether this results from absence of substrate or inability of the enzyme to phosphorylate peak 9 protein could not be determined. When a similar experiment using the cAMP-independent enzyme was performed, there was no labeling of either peak 7 or peak 9 proteins. Again, it was not possible to determine whether this related to lack of substrates in the fraction or to specificity of the enzyme. These experiments indicate that the cAMP-dependent enzyme may act on peak 7 protein although the results with the isolated enzyme indicate that other factors must be present in intact cells to account for the clear stimulation of phosphorylation by thrombin and concomitant inhibition of phosphorylation by agents that elevate cAMP.

\section{DISCUSSION}

Our results indicate that in intact platelets thrombin induces a rapid 2-6-fold increase in phosphorylation of two platelet proteins of approximately 40,000 and 20,000 mol wt as determined by SDS polyacrylamide gel electrophoresis. The phosphate is incorporated into protein as the phosphomonoesters of serine and threonine. We have demonstrated that peak 7 protein migrates the same on SDS gels when either unreduced or reduced with 2-mercaptoethanol. Furthermore, the molecular weight of undenatured, unreduced peak 7 protein as determined by gel filtration on Sephadex G-150 (49,000) was similar to the molecular weight of 40,000 determined by SDS gel electrophoresis. Thus, peak 7 protein is not a covalently linked subunit of a larger protein.

There are many similarities between the characteristics of the platelet release reaction and phosphorylation of peak 7 and peak 9 proteins. The published time of $10-30 \mathrm{~s}$ for half-maximal thrombin-induced release $(33,38,39)$ is similar to the observed time for halfmaximal thrombin-induced phosphorylation of protein peaks 7 and $9(10-14 \mathrm{~s})$. Likewise, the concentration of thrombin required for half-maximal release $(5,38$, $39)$ is similar to the observed concentration of thrombin $(0.25 \mathrm{U} / \mathrm{ml})$ required for half-maximal phosphorylation of peak 7 and peak 9 proteins. DFP-treated thrombin, which binds normally to platelets without inducing the release reaction (3), does not induce peak 7 protein or peak 9 protein phosphorylation. The lectin E-PHA, which binds to the platelet surface, decreases adenylate cyclase activity, and causes the platelet release reaction in washed human platelets (14-33), induces peak 7 protein and peak 9 protein phosphorylation. Thrombin and E-PHA are presumably related in their mode of action on platelets since elevation of intracellular platelet CAMP blocks their initiation of the release reaction $(5,33,40)$. We observed that $\mathrm{PGE}_{1}$ or DB-cAMP inhibited thrombin-induced phosphorylation of peak 7 and 9 proteins. These similarities between the platelet release reaction and phosphorylation of peak 7 and peak 9 suggest a relationship between the two phenomena. However, our data do not indicate whether peak 7 or peak 9 protein phosphorylation is part of the releaseinducing mechanism, a result of the release reaction, or a simultaneous but unrelated event.

In most cAMP-modulated systems an increase in protein phosphorylation follows activation of a cAMPdependent protein kinase by an increase in intracellular cAMP. However, in the intact platelet system the usual positive correlation between cAMP levels and protein phosphorylation does not appear to hold since an increase in intracellular cAMP blocks the thrombininduced peak 7 and peak 9 protein phosphorylation. Several examples of an inverse correlation between a 
change in cAMP concentration and protein phosphorylation have been described in the literature (7-10, 42-45). In toad bladder mucosa it was observed that antidiuretic hormone induced a decrease in phosphorylation of membrane and soluble proteins in association with an increase in intracellular cAMP (7-9). In that system, a decrease in phosphorylation of a specific membrane protein appeared to be the result of both the inhibition of protein kinase activity and the stimulation of phosphoprotein phosphatase activity. Our results do not distinguish between thrombin-induced stimulation of protein kinase activity and thrombin-induced inhibition of phosphoprotein phosphatase activity.

Other mechanisms unrelated to cAMP could explain the thrombin-induced phosphorylation of peak 7 and 9 proteins. First, thrombin might alter the activity of an as yet undescribed guanosine $3^{\prime}, 5^{\prime}$-cyclic monophosphatedependent protein kinase or phosphatase. Second, thrombin could rapidly increase the specific activity of the ATP available to the protein kinase(s) responsible for peak 7 and peak 9 protein phosphorylation. This latter suggestion would be difficult to test since changes in the specific activity of total platelet ATP may not reflect changes in the specific activity of the ATP available to the kinase. Lastly, we observed that there was inhibition of the two protein kinase enzymes by $\mathrm{Ca}^{++}$ in the presence of $\mathrm{Mg}^{++}$and the complete lack of activity when $\mathrm{Mg}^{++}$was absent and $\mathrm{Ca}^{++}$was present. Thus, the secretion of $\mathrm{Ca}^{++}$induced by thrombin during the release reaction (38) could remove the inhibition of the protein kinase(s) responsible for peaks 7 and 9 protein phosphorylation. Possibly the inhibition of phosphorylation by agents that elevate cAMP is due to inhibition of $\mathrm{Ca}^{++}$release by cAMP.

We have shown that in the presence of $\left[\gamma^{32} \mathrm{P}\right] \mathrm{ATP}$, disrupted platelets as well as the supernatant fraction of disrupted platelets phosphorylate endogenous platelet proteins that co-electrophorese with peak 7 and 9 proteins. In contrast to the intact platelet system, this phosphorylation is not affected by cAMP or thrombin.

We cannot easily explain the difference observed in the effect of thrombin and cAMP on protein phosphorylation in intact platelets versus platelet homogenates. However, our results do suggest that the normal control mechanisms of platelet protein kinase and/or phosphoprotein phosphatase activity are disrupted during cell lysis. This suggestion is consistent with earlier observations which indicated that intact platelets were necessary to observe a variety of physiological effects of thrombin (5).

We have observed only minimal phosphorylation of peak 7 and 9 proteins in the particulate fraction of sonicated platelets when the disrupted platelets were incubated with $\left[\gamma_{-}{ }^{32} \mathrm{P}\right]$ ATP before separation into soluble and particulate fractions and none when the isolated particulate fraction was incubated with $\left[\gamma_{-}{ }^{32} \mathrm{P}\right]-$ ATP even though this faction contains $\frac{1}{4-3}$ of the total protein kinase activity when assayed with exogenous substrates.

Contradictory information has been presented in the literature in regard to phosphorylation of the particulate fraction of disrupted platelets. Booyse et al. have reported phosphorylation of two proteins of mol wt 44,000 and 19,000 , using $\left[\gamma^{32} \mathrm{P}\right]$ ATP with particulate fractions from disrupted platelets (46). They suggested that thrombin decreases platelet protein phosphorylation of the $44,000-\mathrm{mol}$ wt band and that cAMP increases platelet membrane phosphorylation. In contrast, Steiner has presented preliminary data suggesting that thrombin increases phosphate incorporation into isolated platelet membranes in the presence of $\left[\gamma^{32} \mathrm{P}\right]$ ATP (47). Insufficient details are available in these reports to make direct comparisons to our results.

Protein kinases can be divided into three major groups (6) : (a) cAMP-regulated, including free catalytic subunit and cAMP-stimulated holoenzyme; $(b)$ cAMPindependent, which includes such enzymes as phosphorylase b kinase (48), histone kinase HK2 (49), phosvitin kinase $(50)$, casein kinase $(51)$, and chromatin protein kinase (52); and (c) the not-so-well characterized cAMP-inhibited enzymes (7-10, 42-45). Four criteria have been established (6) for classifying protein kinases. They were designed before reports of cAMPinhibited protein kinases had appeared and thus are not as applicable to them. They are useful, however, in providing a common base for comparison of enzymes isolated from various tissues within an organism and from various organisms. These parameters are: (a) stimulation by cAMP, (b) binding of cAMP (c) inhibition of activity by the regulatory subunit, and $(d)$ inhibition of activity by the heat-stable inhibitory protein.

We have shown that the supernatant fraction of disrupted platelets can be separated into two distinct protein kinase enzymes. The cAMP-dependent enzyme that we have demonstrated is typical on the basis of the four criteria above-it is stimulated by cAMP, binds $\left[{ }^{3} \mathrm{H}\right]-$ cAMP, and is inhibited by the regulatory subunit and by the heat-stable inhibitor protein. This enzyme has been previously described in platelet extracts $(2,46,53)$. The cAMP-independent enzyme is not affected by the above-mentioned regulatory proteins.

The different protein acceptor substrate specificities of the two separated protein kinase enzymes now explain the results obtained with whole platelet sonicates or the supernatant fraction after centrifugation. The protein kinase activity of these crude preparations when assayed with histone $f_{2 b}$ as substrate was predominantly that of the cAMP-dependent enzyme while the protein kinase activity when assayed with protamine as substrate was 
primarily that of the cAMP-independent enzyme. Thus, the protein kinase activity of the crude fractions when assayed with histone $f_{2 b}$ as substrate was stimulated by cAMP while the activity when assayed with protamine as substrate was only slightly affected by cAMP.

The substrates of the two enzymes in intact platelets have not been determined since the enzymes have not been isolated from all potential substrates. The cAMPdependent enzyme fraction apparently contained one of the substrates of most interest, i.e., peak 7 protein. Phosphorylation of this protein was stimulated by cAMP but not by thrombin. We have thus shown that this enzyme fraction is capable of phosphorylating a protein that co-electrophoreses with peak 7 protein, but whether it actually is responsible for the thrombin-induced increase in phosphorylation of peak 7 protein observed in intact platelets is not known.

The fact that phosphorylation of peak 7 protein is stimulated by CAMP with the fractionated enzyme while cAMP has no effect on peak 7 protein phosphorylation in crude sonicates as well as the fact that agents that elevate the intracellular cAMP levels clearly inhibit thrombin-induced phosphorylation with intact ${ }^{32} \mathrm{PO}_{4}$ loaded platelets indicates that cAMP regulation of a protein kinase is not the sole control mechanism for protein phosphorylation in intact platelets.

The identities of peak 7 and peak 9 protein are not known. However, peak 7 protein migrates with actin in the darkest Coomassie Blue staining region on SDS polyacrylamide gel electrophoresis of platelets (54), while a light chain of platelet myosin has been demonstrated to migrate at a molecular weight similar to peak 9 protein $(55,56)$. Preliminary experiments have suggested that peak 7 protein is not actin but that peak 9 protein may be the light chain of platelet myosin. Purification of peak 7 and 9 proteins will help to clarify their identity and location, their interaction with the platelet protein kinases, and their role in the platelet release reaction.

\section{ACKNOWLEDGMENTS}

We thank the St. Louis Chapter of the American Red Cross and the Barnes Hospital Blood Bank for making available the fresh platelet-rich plasma and 72-h-old platelet concentrates. We thank Dr. Lewis Chase for his helpful discussions about the phosphodiesterase assay.

This work was supported by grants from the National Institutes of Health, HE 14147 and HL 16634.

\section{REFERENCES}

1. Lyons, R. M., and P. W. Majerus. 1974. The effect of thrombin on protein phosphorylation in human platelets. J. Clin. Invest. 53: 48a. (Abstr.)

2. Salzman, E. W., and W. Weisenberger. 1972. Role of cyclic AMP in platelet function. Adv. Cyclic Nucleotide Res. 1: 231-247.
3. Tollefsen, D. M., J. R. Feagler, and P. W. Majerus. 1974. The binding of thrombin to the surface of human platelets. J. Biol. Chem. 249: 2646-2651.

4. Ganguly, P. 1974. Binding of thrombin to human platelets. Nature (Lond.). 247: 306-307.

5. Brodie, G. N., N. L. Baenziger, L. R. Chase, and P. W. Majerus. 1972. The effects of thrombin on adenyl cyclase activity and a membrane protein from human platelets. J. Clin. Invest. 51: 81-88.

6. Walsh, D. A., and E. G. Krebs. 1973. Protein kinases. In The Enzymes. P. D. Boyer, editor. Academic Press, Inc., New York. 3rd edition. 8: 555-581.

7. DeLorenzo, R. J., and P. Greengard. 1973. Activation by adenosine $3^{\prime}: 5^{\prime}$-monophosphate of a membrane-bound phosphoprotein phosphatase from toad bladder. Proc. Natl. Acad. Sci. U. S. A. 70: 1831-1835.

8. Liu, A. Y-C., and P. Greengard. 1974. Aldosteroneinduced increase in protein phosphatase of toad bladder. Proc. Natl. Acad. Sci. U. S. A. 71: 3869-3873.

9. DeLorenzo, R. J., K. G. Walton, P. F. Curran, and P. Greengard. 1973. Regulation of phosphorylation of a specific protein in toad-bladder membrane by antidiuretic hormone and cyclic AMP, and its possible relationship to membrane permeability changes. Proc. Natl. Acad. Sci. U. S. A. 70: 880-884.

10. Kish, V. M., and L. J. Kleinsmith. 1974. Nuclear protein kinases. J. Biol. Chem. 249: 750-760.

11. Reynolds, J. A., and M. J. Schlesinger. 1967. Conformational states of the subunit of Escherichea coli alkaline phosphatase. Biochemistry. 6: 3552-3559.

12. Glover, C., and E. Shaw. 1971. The purification of thrombin and isolation of a peptide containing the active center histidine. J. Biol. Chem. 246: 4594-4601.

13. Kostka, V., and F. H. Carpenter. 1964. Inhibition of chymotrypsin activity in crystalline trypsin preparations. J. Biol. Chem. 239: 1799-1803.

14. Majerus, P. W., and G. N. Brodie. 1972. The binding of phytohemagglutinins to human platelet membranes. J. Biol. Chem. 24: 4253-4257.

15. Baenziger, N. L., and P. W. Majerus. 1974. Isolation of human platelets and platelet surface membrane. Methods Enzymol. 31: 149-155.

16. Weber, K., and M. Osborn. 1969. The reliability of molecular weight determinations by dodecyl sulfatepolyacrylamide gel electrophoresis. J. Biol. Chem. 244 : 4406-4412.

17. Bray, G. A. 1960. A simple, efficient liquid scintillator for counting aqueous solutions in a liquid scintillation counter. Anal. Biochem. 1: 279-285.

18. Laemmli, U. K. 1970. Cleavage of structural proteins during the assembly of the head of bacteriophage $\mathrm{T} 4$ Nature (Lond.). 227: 680-685.

19. Reid, M. S., and R. L. Bielski. 1968. A simple apparatus for vertical flat-sheet polyacrylamide gel electrophoresis. Anal. Biochem. 22: 374-381.

20. Baenziger, N. L., G. N. Brodie, and P. W. Majerus. 1972. Isolation and properties of a thrombin-sensitive protein of human platelets. J. Biol. Chem. 247: 27232731.

21. Corbin, J. D., C. O. Brostrom, C. A. King, and E. G. Krebs. 1972. Studies on the adenosine $3^{\prime}, 5^{\prime}$-monophosphate-dependent protein kinases of rabbit skeletal muscle. J. Biol. Chem. 247: 7790-7798.

22. Reimann, E. M., D. A. Walsh, and E. G. Krebs. 1971. Purification and properties of rabbit skeletal muscle adenosine $3^{\prime} 5^{\prime}$-monophosphate-dependent protein kinases. J. Biol. Chem. 246: 1986-1995. 
23. Reimann, E. M., C. O. Brostrom, J. D. Corbin, C. A. King, and E. G. Krebs. 1971. Separation of regulatory and catalytic subunits of the cyclic $3^{\prime}, 5^{\prime}$-monophosphatedependent protein kinase(s) of rabbit skeletal muscle. Biochem. Biophys. Res. Commun. 42: 187-194.

24. Walsh, D. A., C. D. Ashby, C. Gonzalez, D. Calkins, E. H. Fischer, and E. G. Krebs. 1971. Purification and characterization of a protein inhibitor of adenosine $3^{\prime}, 5^{\prime}$-monophosphate-dependent protein kinases. J. Biol. Chem. 246: 1977-1985.

25. Hunter, W. M. 1967. The preparations of radioiodinated proteins of high activity. Their reaction with antibody in vitro: the radioimmunoassay. In Handbook of Experimental Immunology. D. M. Weir, editor. Blackwell Scientific Publications, Ltd., London. 608-654.

26. Ackers, G. K. 1964. Molecular exclusion and restricted diffusion processes in molecular-sieve chromatography. Biochemistry. 3: 723-730.

27. Sanborn, B. M., R. C. Bhalla, and S. G. Korenman. 1973. The endometrial adenosine cyclic $3^{\prime}, 5^{\prime}$-monophosphate-dependent protein kinase. J. Biol. Chem. 248: 3593-3600.

28. Walton, G. M., and L. D. Garren. 1970. An assay for adenosine $3^{\prime}, 5^{\prime}$-cyclic monophosphate based on the association of the nucleotide with a partially purified binding protein. Biochemistry. 9: 4223-4229.

29. Beavo, J. A., J. G. Hardman, and E. W. Sutherland. 1970. Hydrolysis of cyclic guanosine and adenosine $3^{\prime}, 5^{\prime}-$ monophosphates by rat and bovine tissues. J. Biol. Chem. 245: 5649-5655.

30. Linhardt, K., and K. Walter. 1965. Phosphatases. In Methods of Enzymatic Analysis. H. U. Bergmeyer, editor. Academic Press, Inc., New York. 779-787.

31. Seegers, W. H., and H. P. Smith. 1942. Factors which influence the activity of purified thrombin. Am. J. Physiol. $137:$ 348-354.

32. Lowry, O. H., N. J. Rosebrough, A. L. Farr, and R. J. Randall. 1951. Protein measurement with the folin phenol reagent. J. Biol. Chem. 193: 264-275.

33. Tollefsen, D. M., J. R. Feagler, and P. W. Majerus. 1974. Induction of the platelet release reaction by phytohemagglutinin. J. Clin. Invest. 53: 211-218.

34. Cohen, P., M. J. Broekman, A. Verkley, J. W. W. Lisman, and A. Derksen. 1971. Quantification of human platelet inositides and the influence of ionic environment on their incorporation of orthophosphate- ${ }^{32} \mathrm{P}$. J. Clin. Invest. 50: 762-772.

35. Taborsky, G. 1974. Phosphoproteins. Adv. Protein Chem. 28: 1-210.

36. Schmidt, G. 1957. Chemical and enzymatic methods for the identification and structural elucidation of nucleic acids and nucleotides. Methods Enzymol. 3: 747-775.

37. Allerton, S. E., and G. E. Perlman. 1965. Chemical characterization of the phosphoprotein phosvitin. J. Biol. Chem. 240: 3892-3898.

38. Detwiler, T. C., and R. D. Feinman. 1973. Kinetics of the release of $\mathrm{Ca}$ (II) by platelets. Biochemistry. 12: 282-289.

39. Detwiler, T. C., and R. D. Feinman. 1973. Kinetics of the thrombin-induced release of adenosine triphosphate by platelets. Comparison with release of calcium. Biochemistry. 12: 2462-2468.
40. Wolfe, S. M., and N. R. Shulman. 1970. Inhibition of platelet energy production and the release reaction by $\mathrm{PGE}_{1}$, theophylline and cAMP. Biochem. Biophys. Res. Commun. 41: 128-134.

41. Corbin, J. E., T. R. Soderline, and C. R. Park. 1973. Regulation of adenosine $3^{\prime}, 5^{\prime}$-monophosphate-dependent protein kinase. I. Preliminary characterization of the adipose tissue enzyme in crude extracts. J. Biol. Chem. 248: 1813-1821.

42. Miyamoto, E., J. F. Kuo, and P. Greengard. 1969. Cyclic nucleotide-dependent protein kinases. III. Purification and properties of adenosine $3^{\prime}, 5^{\prime}$-monophosphatedependent protein kinase from bovine brain. J. Biol. Chem. 244: 6395-6402.

43. Kuo, J. F., B. K. Krueger, J. R. Sanes, and P. Greengard. 1970. Cyclic nucleotide-dependent protein kinases. V. Preparation and properties of adenosine 3',5'monophosphate-dependent protein kinase from various bovine tissues. Biochim. Biophy's. Acta. 212: 79-91.

44. Johnson, E. M., H. Maeno, and P. Greengard. 1971. Phosphorylation of endogenous protein of rat brain by the cyclic adenosine $3^{\prime}, 5^{\prime}$-monophosphate-dependent protein kinase. J. Biol. Chem. 246: 7731-7739.

45. Kuehn, G. D. 1972. Cell cycle variation in cyclic adenosine 3',5'-monophosphate-dependent inhibition of a protein kinase from Physarum Polycephalum. Biochem. Biophy's. Res. Commun. 49: 414-419.

46. Booyse, F. M., D. Guiliani, J. J. Marr, and M. E. Rafelson, Jr. 1973. Cyclic adenosine $3^{\prime}, 5^{\prime}$-monophosphate dependent protein kinase of human platelets: membrane phosphorylation and regulation of platelet function. Ser. Haematol. 6 : 351-366.

47. Steiner, M. 1974. Effect of thrombin on phosphorylation of platelet membrane proteins. Blood. 44: 916. (Abstr.)

48. Krebs, E. G., and E. H. Fischer. 1956. The phosphorylase $\mathrm{b}$ to a converting enzyme of rabbit skeletal muscle. Biochim. Biophy's. Acta. 20: 150-157.

49. Langan, T. A. 1971. Cyclic AMP and histone phosphorylation. Ann. N. Y. Acad. Sci. 185 : 166-180.

50. Rodnight, R., and B. E. Lavin. 1964. Phosvitin kinase from brain: activation by ions and subcellular distribution. Biochem. J. 93: 84-91.

51. Bingham, E. W., H. M. Farrell, Jr., and J. J. Basch. 1972. Phosphorylation of casein. Role of the Golgi apparatus. J. Biol. Chem. 247: 8193-8194.

52. Takeda, M., H. Yamamura, and Y. Ohga. 1971. Phosphoprotein kinases associated with rat liver chromatin. Biochem. Biophys. Res. Commun. 42: 103-110.

53. Marquis, N. R., R. L. Vigdahl, and P. A. Tavormina. 1971. Cyclic AMP-dependent platelet protein kinase. Fed. Proc. 30: 423. (Abstr.)

54. Pollard, T. D., S. M. Thomas, and R. Niederman. 1974. Human platelet myosin. I. Purification by a rapid method applicable to other nonmuscle cells. Anal Biochem. 60: 258-266.

55. Adelstein, R. S., M. A. Conti, and W. Anderson, Jr. 1973. Phosphorylation of human platelet myosin. Proc. Natl. Acad. U.S. A. 70: 3115-3119.

56. Conti, M. A., and R. S. Adelstein. 1975. Platelet myosin phosphorylation controls actin activation of myosin ATPase activity. Fed. Proc. 34: 670. (Abstr.) 